\title{
PREMISSAS PARA APLICAÇÃo DE ANÁLISE FÍLMICA À PUBLICIDADE AUDIOVISUAL: UM EXERCíCIO ANALÍTICO DE ALWAYS A WOMAN
}

\author{
TATIANA GUENAGA ANEAS
}


PREMISSAS PARA APLICAÇÃO DE ANÁLISE FÍLMICA À PUBLICIDADE AUDIOVISUAL: UM EXERCÍCIO ANALÍTICO DE ALWAYS A WOMAN

Resumo: Este artigo tem como objetivo assinalar os aspectos específicos do comercial televisivo, e sugerir, a partir de uma perspectiva imanente, uma abordagem metodológica que dê conta da relação entre sua dimensão fílmica e a dimensão promocional. Com o objetivo de demonstrar o funcionamento da abordagem proposta, analisamos o comercial Always a Woman, da marca Jonh Lewis.

Palavras-chave: filme publicitário, comercial televisivo, análise fílmica.

SUPUESTO DE APLICACIÓN DE LA ANÁLISIS FÍLMICA A LA PUBLICIDAD AUDIOVISUAL: UN EJERCICIO ANALITICO DE ALWAYS A WOMAN

Resumen: Este trabajo tiene como objetivo destacar los aspectos específicos del comercial de TV, y sugerir, desde una perspectiva inmanente, un enfoque que tiene en cuenta la relación entre sus dimensiones fílmica e de promoción. Para demostrar el funcionamiento del enfoque propuesto, se analiza el comercial Always a Woman, de la marca John Lewis

Palabras clave: film publicitario, comercial de TV, analisis filmica.

ASSUMPTIONS FOR APLICATION OF FILM ANALYSIS TO AUDIOVISUAL ADVERTISING: AN ANALYTICAL EXERCISE ON ALWAYS A WOMAN

Abstract: This paper aims to point out the specific aspects of the television commercial, and suggest, from an immanent perspective, an approach that takes into account the relationship between their filmic and promotional dimensions. In order to demonstrate the operation of the proposed approach, we analyze the ad Always a Woman, by John Lewis.

Keywords: advertising film, television commercial, filmic analysis. 


\section{INTRODUÇÃO}

No campo de estudos sobre o audiovisual, existe uma longa tradição de análise que se dedica a investigar os modos de construção e funcionamento das obras, sendo que a maioria dos trabalhos se encontra na área de cinema. Desde o estruturalismo, pesquisadores do Brasil e do mundo adotaram diversos vieses para escrutinar filmes - semioticistas, psicanalíticos, narratológicos, cognitivistas, para citar os mais utilizados. Pouco depois do cinema, produtos como a telenovela, os seriados e os videoclipes passam a ser observados a partir destas perspectivas mais imanentistas ou textualistas. Em cada caso, evidencia-se uma preocupação em observar os elementos específicos de cada produto. Certamente por isso que estudos sobre seriados televisivos tendam a privilegiar o caráter de serialidade da narrativa, ou que a análise de videoclipes tenha foco na relação entre música e narrativa audiovisual, por exemplo.

Pensando na publicidade audiovisual exibida nas emissoras de televisão e nos grandes festivais, de uma perspectiva interna, o que seria específico do comercial? Do ponto de vista da relação que um produto audiovisual estabelece com o espectador', é sabido que do seu propósito podem derivar diferentes regimes de interpretação. Um telejornal intenta prioritariamente o oferecimento de informações sobre o estado atual do mundo experimentado, que devem ser tomadas como verídicas. Um filme ou série televisiva objetivam sobretudo proporcionar experiências fruitivas, dispõem-se a serem apreciados de alguma maneira. São diferentes contratos de leitura, no sentido atribuído por Eco (1994).

Os propósitos de um filme publicitário, por sua vez, encontram-se na esfera do promocional: trata-se de divulgar, propagandear, fazer conhecer um produto, uma marca, uma empresa ou instituição, um governo ou estado, uma pessoa, uma posição política ou ideológica, uma ideia ou questão pública. Pensando em um programa de efeitos (Gomes, 2004) é possível afirmar que, de maneira genérica, um comercial pretende produzir determinado engajamento emocional da parte do espectador. E a produção de qualquer espécie de disposição deve ser necessariamente vantajosa do ponto de vista promocional.

É evidente que, nos produtos da comunicação contemporânea, não são raros os casos em que estes limites perdem seus contornos nítidos. Trata-se,

1 Espectador aqui entendido como uma "instância textual”, abstraído do filme. 
PREMISSAS PARA APLICAÇÃO DE ANÁLISE FÍLMICA À PUBLICIDADE AUDIOVISUAL

muito mais, de uma questão de predominância do que de atribuição de propriedades estanques. Em contrapartida, é uma prevalência absolutamente essencial para caracterizar o produto enquanto tal - um filme de duração resumida em meio à programação televisiva, que apenas se preste à apreciação e não promova coisa alguma, não será um filme publicitário. Ou, ao menos, não será assim percebido - o que, em essência, é a mesma coisa.

Do ponto de vista analítico, o fato de que comerciais são produzidos por essa razão e com esse objetivo é uma face da sua constituição que pode e deve ser pressuposta. A dimensão promocional, portanto, é um aspecto necessário do filme publicitário. O que não significa dizer, em absoluto, que seja o único. A publicidade existe para promover algo, mas como, em se tratatando de matéria audiovisual, isso acontece?

Embora seja forçoso o seu comparecimento, a dimensão promocional pode se materializar através de diferentes estratégias, a depender sobretudo do objeto publicitado, do público a que se destina e do seu objetivo enquanto parte de um esforço maior de comunicação. Certos filmes se concentram essencialmente na construção da imagem do seu anunciante - que pode ser uma empresa, uma marca, um produto, um partido político, dentre outros. As peças buscam atribuir-lhe determinadas qualidades que podem ser mais ou menos concretas. Outros pretendem um efeito mais imediato, incentivando diretamente o consumo. Alguns ainda se localizam a meio caminho, combinando artifícios. Em todos os casos, porém, existe o intuito de provocar certa afetação, de atuar sobre o estado de ânimo do receptor - seja para a introdução de uma novidade, a mudança ou a manutenção do modo de perceber a matéria de que trata o filme.

Assim, um comercial de uma empresa de segurança privada poderá angariar a adesão do seu consumidor narrando fatos que inspirem confiança e tranquilidade, ao passo em que o comercial de uma marca de chocolates poderá estimular seu receptor sensorialmente com belas imagens com o intuito de produzir a vontade de consumir o alimento. Um fabricante de roupas de luxo buscará explorar as vantagens sociais e psicológicas que o consumo dos seus produtos pode proporcionar, enquanto uma grande magazine popular se inclinará a defender o custo-benefício das suas ofertas, apresentando variedade de modelos, preços e facilidades de pagamento. São diferentes artifícios per- 
suasivos que buscam, por algum caminho, conquistar ou manter uma atitude ${ }^{2}$ positiva do receptor/consumidor frente ao objeto publicitado.

Diferentes objetivos promocionais requerem diferentes tipos de representação audiovisual - e até uma mesma finalidade nesse sentido pode se apresentar de diversas formas. É neste ponto que a dimensão promocional toca um outro aspecto fundamental do filme publicitário: a dimensão fílmica. Ou seja, aquela que diz respeito aos modos de construir e encenar composições audiovisuais.

Enquanto filme, o comercial solicita a produção de certas respostas do seu receptor, que podem ser de caráter emocional, cognitivo ou sensorial (GOMES, 2004). Em muitos casos, há a combinação destas categorias, embora seja comum também a ocorrência de predominância de uma delas. O fato é que existe uma face dos filmes publicitários que pretende emocionar, surpreender, sensibilizar, amedrontar, informar, compadecer, desorientar, conscientizar, fazer refletir, atiçar os sentidos, arrancar lágrimas ou gargalhadas de seus apreciadores - produzir efeitos, em suma. E ainda que exista uma finalidade última inscrita na necessária dimensão promocional, esta não anula a experiência proporcionada pelo filme comercial - a experiência estética de uma narrativa audiovisual, com todas as dimensões de técnicas e recursos inscritas neste tipo de produto. Por recursos, entendemos desde a construção da ação e caracterização dos personagens, até a variação da escala de planos, enquadramento, montagem, luz, cor, profundidade de campo e todos os parâmetros fotográficos, além da música e elementos sonoros.

Importante salientar que, nesse caso, tais efeitos não são disparados por meio de estratégias propriamente publicitárias. Não é apenas a disposição de uma empresa de portar-se como aquela que "você conhece, você confia", ou de programar centenas de inserções diárias no break, que garantirá qualquer percepção por parte do espectador. Nenhum plano de marketing ou estratagema promocional é capaz de suscitar paixões de qualquer natureza. No filme publicitário, são as estratégias de produção de efeitos as responsáveis por acionar os botões corretos do mecanismo perceptivo do espectador, em um movimento que engendra uma disposição adequada e vantajosa para o anunciante - a

2 Atitude aqui entendida ao modo dos cognitivistas, como uma disposição, uma etapa anterior ao comportamento. 
PREMISSAS PARA APLICAÇÃO DE ANÁLISE FÍLMICA À PUBLICIDADE AUDIOVISUAL

depender, evidentemente, da habilidade de quem orquestra tais ardis.

Se a divulgação de um produto é um imperativo a este formato audiovisual, as maneiras com que essa tarefa pode ser levada à cabo são variáveis. Em se tratando de matéria fílmica, este maquinário que estrutura o comercial é arquitetado com base em formas narradas a partir de recursos imagéticos e sonoros que, normalmente, apresentam personagens em ação. E é neste aspecto que o filme publicitário se aproxima de seus parentes audiovisuais. Como em qualquer filme, a narração no comercial pode se dar basicamente através da sucessão de imagens, da música e dos sons, do discurso verbal escrito ou falado, sendo que sua utilização se dá comumente em associação. São incontáveis as maneiras com que o comercial pode arquitetar suas estratégias de forma a posicionar o espectador de determinada maneira dentro do seu universo ficcional.

O aspecto mais evidente da dimensão promocional neste tipo de narrativa é a invariável presença de uma marca. Todo filme publicitário, incluindo os que não têm um objetivo literal de venda, possui signos que se referem ao seu anunciante e que geralmente se apresentam na forma de um símbolo ou logotipo (a chamada identidade visual) e de uma assinatura (ou slogan) escrita e/ ou sonora. Mas não é apenas pela presença de uma marca que é possível inferir a dimensão promocional da publicidade audiovisual narrativa. O discurso nela presente, em geral, leva o espectador a mobilizar seu aparato perceptivo de maneira a relacionar os efeitos suscitados na apreciação da narrativa à percepção relativa à marca que assina o filme. $E$ isso no que diz respeito às dimensões cognitiva, sensorial e emocional. Assim, a narrativa de um comercial como Mr. Long Legs3 irá se esforçar em suscitar uma série de sentimentos e sensações positivos relativos ao bem-estar associado a uma viagem para promover o cartão de viagens do RBC. Ou um filme da Anistia Internacional como Signature4 tentará convencer o espectador da necessidade de se comover com aqueles que sofrem com a ausência dos direitos humanos.

A título de síntese, o que aqui se defende é que existe uma lógica própria do filme publicitário que é resultado da interação entre estas duas dimensões

3 Disponível em http://www.youtube.com/watch?v=8gy7gP1EZOM\&list=UU37ZVZONaWo-W1UhoApN_Jw\&index $=2 \&$ feature $=$ plcp

4 Disponível em http://www.youtube.com/watch?v=wmtlt97_O2k\&feature=plcp\&context= C485bdcbVDvjVQa1PpcFNladsK7UYsgBKk079LocVKSYbDGqiSPTw\%3D 
fundamentais - a fílmica e a promocional. É provável que a primeira esteja a serviço da segunda, uma vez que a função de promover está no DNA deste tipo de produto e é mesmo a sua razão de existir. Mas tampouco existiria o filme publicitário tal e qual hoje é conhecido não fosse a sua exímia capacidade de incitar os afetos, conduzir os raciocínios e provocar os sentidos dos seus espectadores. Ao se apropriar desta premissa, o analista pode contar com ferramentas de análise fílmica, em geral projetadas para o exame de obras cinematográficas, e utilizá-las na análise de filmes publicitários, sem perder de vista o que é específico deste tipo de produto.

\section{CONDUZINDO UMA ANÁLISE DE FILME PUBLICITÁRIO}

Pressupondo que o filme publicitário tenha duas dimensões fundamentais, o que se propõe é uma postura analítica endereçada para os modos de acomodação entre estes dois estratos. O percurso de análise deve contemplar tanto o modo de construção da narrativa e arrumação dos recursos audiovisuais, passando pelos efeitos gerados pela apreciação do material e chegar às consequências deste programa para a percepção de uma marca. Desta forma, a análise poderá dar conta da construção fílmica, do propósito promocional e, também, da relação que se estabelece entre estas duas dimensões.

Com o intuito de demonstrar o funcionamento da perspectiva proposta, analisamos o filme Always a Woman, lançado em junho de 2010 pela rede varejista britânica John Lewis como parte de uma campanha institucional e que teve ampla repercussão entre público e crítica. Criada pela equipe da Adam \& Eve, sob comando de Ben Priest, diretor de criação a peça foi vencedora de um Silver Lion no Festival de Cannes do mesmo ano. A produção, estimada em 6 milhões de euros, é assinada pela Blink. Douglas Wilson foi contratado para a direção, e a pós-produção ficou ao encargo da MPC de Londres. A música, She's Always a Woman, é um clássico de Billy Joel interpretado por Fyfe Dangerfields, vocalista da banda The Guillemots.

A John Lewis é uma cadeia de lojas de departamentos com mais de um século de mercado que comercializa de eletrônicos e móveis a roupas e cosméticos. Seu slogan, “Never Knowingly Undersold”5, é usado há oitenta anos. É

5 A tradução literal seria "Nunca desvalorizado conscientemente". Textos divulgados pela 
PREMISSAS PARA APLICAÇÃO DE ANÁLISE FÍLMICA À PUBLICIDADE AUDIOVISUAL

uma marca muito conhecida dos ingleses, em especial das mulheres de classe média. A maior parte do público, portanto, nasceu em um período em que a empresa já existia e era popular.

O filme constrói sua representação apostando nesta relação de longo prazo. Acompanhando a vida de uma mulher e mostrando cada uma das suas etapas, a marca é apresentada como algo que está sempre presente - até porque a decoração cenográfica e o figurino foram compostos com produtos John Lewis. Os atributos que o filme evoca são percebidos como características da empresa por relação direta: longevidade, confiança, tradição.

E a poética fílmica por trás desta estratégia de construção de imagem está baseada sobretudo na produção de emoções agradáveis. A resposta solicitada ao espectador é um estado de espírito que comporta elementos como ternura, tranquilidade, prazer, bem-estar, além de uma tristeza suave e resignada. É um filme feito para emocionar, de maneira convencional, resultando em uma disposição afetiva positiva com relação ao anunciante. Não há argumento a ser defendido, tampouco a divulgação de um atributo ou evento concretos - como o lançamento da nova coleção de inverno ou a possibilidade de parcelamento em até doze vezes. Trata-se apenas de acionar as teclas anímicas necessárias para gerar essa atitude, transferida para a empresa que assina a peça. As formas e conteúdos convencionais garantem a redundância do filme, de maneira que o espectador médio seja capaz de interpretá-lo e, principalmente, de identificar-se com as situações apresentadas.

A fábula do filme resume a vida de uma mulher da sua infância à terceira idade. São quinze situações ilustrativas de cada fase, distribuídas em noventa segundos. Os fragmentos são selecionados de maneira que formam uma história que corresponde a um padrão, um esquema daquilo que o espectador imagina ser uma vida boa e convencional: infância, juventude, casamento, filhos, trabaIho, netos, velhice. Em todos os contextos, a família está incluída, e as situações nunca envolvem conflitos graves ou sofrimento. Mesmo a cena em que pai e

empresa no seu website ( $w w w$.johnlewis.com) dão conta de que a ideia original da expressão, criada em 1925, seria afirmar que a empresa cobre as ofertas da concorrência, nunca vendendo o mesmo produto por um preço maior. Uma pesquisa divulgada no portal Brandrepublic.com, porém, mostra que, atualmente, $21 \%$ dos ingleses interpreta o slogan com o sentido oposto. Uma tradução possível do sentido atual do slogan para o português seria a expressão "Ninguém faz por menos". 
filhos discutem, é tomada como um conflito banal, sem importância. Da mesma forma, o momento em que a menina suja a cozinha de farinha, ou quando a personagem principal, ainda criança, leva uma bronca da professora por brincar com um aviãozinho de papel, são tomados como travessuras sem consequências, coisas de criança. Funcionam como uma pequena dose de graça.

A fábula trata de apresentar, portanto, não apenas uma história tranquila e feliz, mas sobretudo uma representação convencional, em sentido sociológico. Nas ações dos personagens não se notam desvios de comportamento com relação ao que é considerado aceitável ou desejável do ponto de vista social - definitivamente, não há lugar para filhos fora do casamento, dívidas, adolescentes drogados ou velhos deprimidos. É uma história idealizada, que explora a crença do espectador na importância dos laços familiares e dos valores tradicionais. Os poucos fatos que poderiam ser considerados menos convencionais (como um casamento interracional) têm sua importância minorada - o filme não parece preocupado em escancará-los. É como se estivessem ali apenas na medida em que sua apresentação é politicamente correta, sem chegar ao ponto de macular a ordem estabelecida.

Esse esquema expresso na fábula, por sua vez, é derivado de representações fortemente codificadas presentes em um nível abaixo da estrutura: o das próprias cenas. Cada uma das situações é emblemática, elas são muito representativas, no sentido de que significam sem ambiguidades os momentos da vida da personagem. São cenas generalizáveis, como que pinçadas da vida de uma pessoa comum. Afinal, qualquer criança vai à escola na idade da personagem, assim como comemoram seu aniversário com velas e balões se soprar. A passagem para a vida de casada é marcada com o plano que mostra o momento exato em que os noivos selam a união com um beijo no altar. A gravidez fica muito evidente no plano-americano lateral que apresenta a personagem "assaltando" a geladeira, da mesma maneira com que o primeiro-plano da jovem senhora com uma jarra nas mãos mostra claramente a passagem do tempo nas rugas e nos cabelos brancos.

Em suma, são momentos-chave compartilhados e vividos certamente por boa parte do público. Afinal, aquela poderia ser a representação esquemática da vida de muitos ingleses de classe média. Esse tipo de estratégia compositiva é fundamental para que o espectador se identifique com a história e se 
PREMISSAS PARA APLICAÇÃO DE ANÁLISE FÍLMICA À PUBLICIDADE AUDIOVISUAL

posicione como semelhante à personagem. O que, por sua vez, é de extrema importância na deflagração das emoções.

Importante notar que, neste caso, essas emoções são solicitadas em tom contínuo. Não há grandes variações na matiz poética do comercial, não há estratégias no sentido de modificar ou subverter os efeitos suscitados em algum ponto da narrativa. Há sim um movimento do filme no sentido de aproveitar ao máximo as oportunidades de provocar as emoções. A ponto de tornar as estratégias evidentes para apreciadores mais experientes. Sua gramática aproxima-se, nesse sentido, do padrão melodramático. Embora um tipo específico de recepção possa considerar excessivo o acento emocional, é fato que a condição afetiva do espectador permanece relativamente estável.

Além de ser uma estratégia promocional cujas estratégias fílmicas são observáveis analiticamente, é preciso mencionar que o acento emotivo de Always a Woman foi imediatamente percebido pela recepção empírica. A crítica de Viv Groskop, publicada no blog de rádio e televisão do portal do The Guardian, ilustra bem a maneira como o comercial foi recebido: "Esta poderia ser a mais nauseante propaganda na história da televisão - ao invés disso, a Adam \& Eve, agência da John Lewis, criou uma obra-prima da manipulação emocional em 91 segundos" (tradução nossa) ${ }^{6}$.

A narrativa é baseada na pura apresentação destas situações. Não há intenção de dispor os fatos narrativos de forma intrincada. Ao contrário, as mudanças na vida da personagem são tratadas de maneira a serem percebidas como naturais. As passagens são muito suaves, e boa parte da engenhosidade do filme reside na construção das elipses. Certamente há uma função de compressão temporal - afinal, são setenta anos resumidos em um minuto e meio e, além de serem muitas, as elipses correspondem a longos intervalos temporais. Mas a ordenação (cronológica) com que as situações são dispostas na linha do tempo narrativo e, principalmente, a impressão de contiguidade visual entre as cenas conferem aos acontecimentos um sentido intenso de fluidez.

Este sentido é igualmente orquestrado com recursos de mostração. A estratégia mais evidente para gerar essa impressão de continuidade narrativa e fluidez temporal é através das passagens entre as situações. Os cortes na mon-

6 This should be the most nauseating advert in the history of television - instead John Lewi's agency Adam \& Eve has created a masterclass in emotional manipulation in 91 seconds. 
tagem e as mudanças de cena são camuflados por meio de diversos truques. O mais recorrente deles é o movimento de câmera. Com frequência, o ponto de vista oferecido se desloca de maneira a passar por um elemento cênico que disfarça os cortes. Para o espectador, a impressão é de que há continuidade, mas os personagens de fato saem do quadro. É o caso da cena do casamento, quando os personagens atravessam uma porta (Figuras 1, 2, 3), ou quando eles já idosos caminham no campo com os netos e passam por trás de um arbusto.

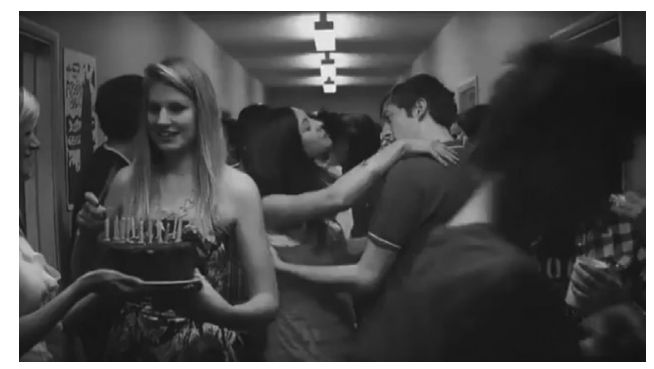

Figura 1

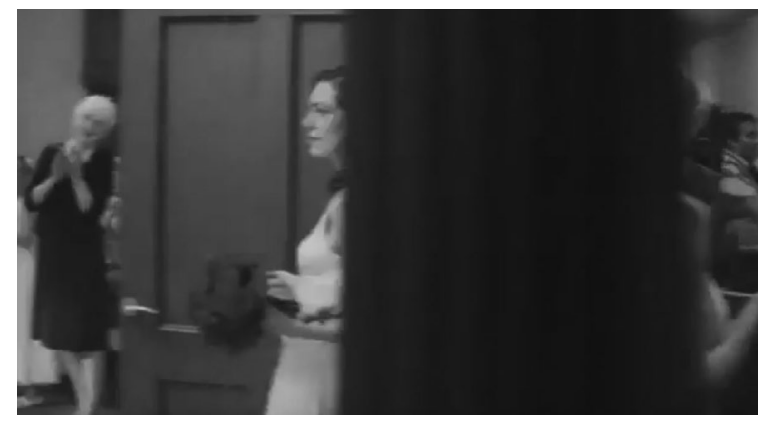

Figura 2

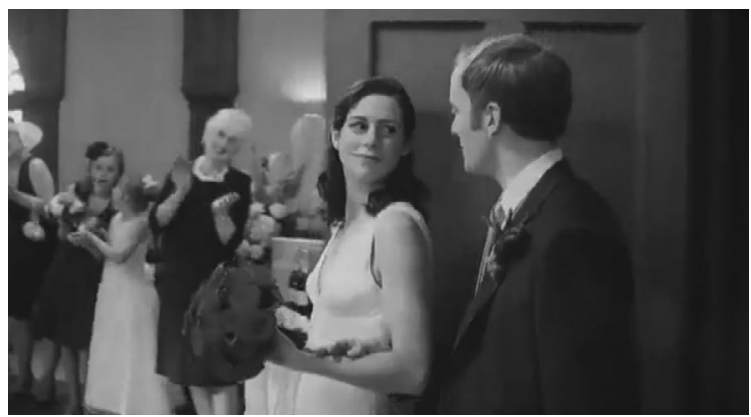

Figura 3

Há outros recursos que são utilizados nesse sentido - especificamente, cenários, enquadramento e iluminação. Em três ocasiões, o cenário é composto por dois ambientes colados, e a transição é feita apenas com o deslocamento lateral da perspectiva ótica oferecida. No primeiro plano do filme, é o enquadramento que cumpre essa função: o bebê sai de quadro ao ser carregado no colo da mãe, enquadrada da cintura para baixo, e quando volta ao chão já é uma criança de dois anos. Na transição entre a cena da escola e a do aniversário de seis anos, é o uso da luz que funciona nesse sentido. Um efeito de reflexão da luz no interior da objetiva conhecido como flare ofusca o espectador por um segundo, o suficiente para a mudança de cena (figuras 4, 5 e 6). 


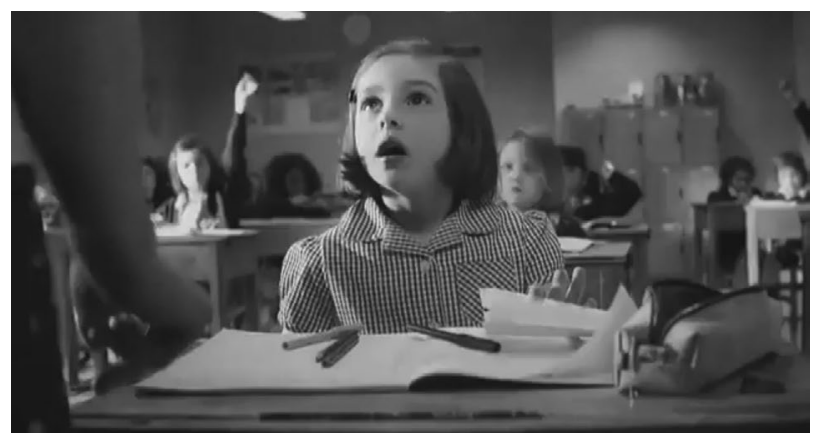

Figura 4

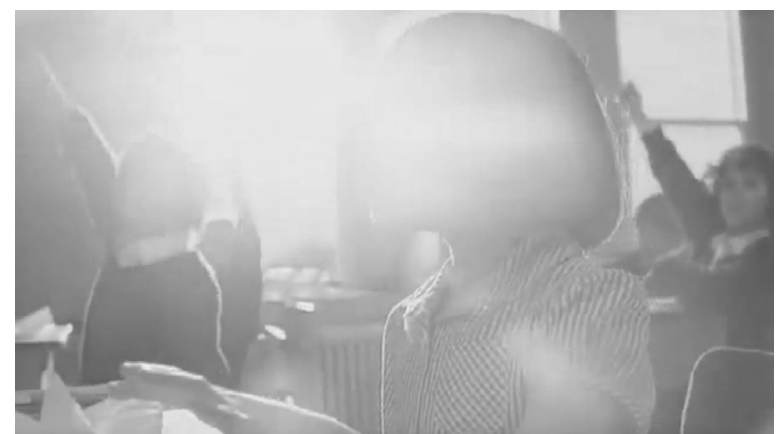

Figura 6

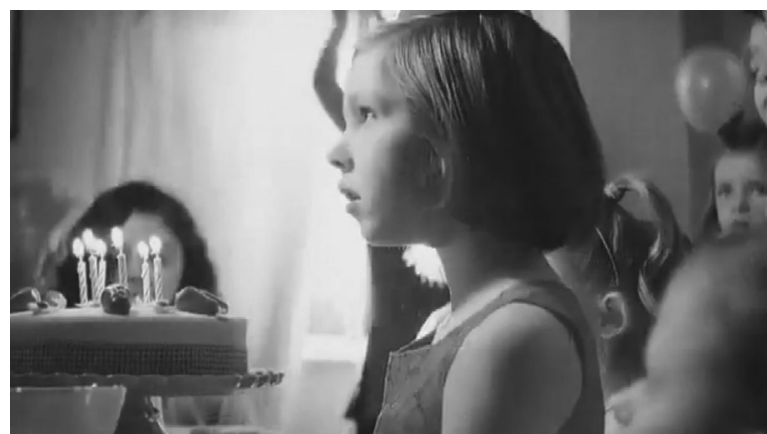

Figura 5

Além de compor esta continuidade, tais truques podem gerar um outro efeito: certo prazer estético derivado da sensação de se estar diante de uma representação engenhosa. Embora a convenção esteja presente sobretudo na história que é contada, o contrato proposto ao espectador prevê uma brecha para a inovação formal.

O figurino da personagem principal é mais um elemento fundamental na composição desta estratégia de continuidade visual. A personagem está sempre vestida de vermelho - mesmo quando ela vai se casar, de vestido branco, as flores em suas mãos e cabelos são vermelhas. Em todas as demais cenas, sua roupa é desta cor, o que reforça a impressão de que se trata da mesma pessoa em momentos diferentes. Além disso, há a movimentação da câmera, que não para em nenhum momento. $O$ fato de ela estar sempre em movimento provoca a sensação de se estar diante de acontecimentos contínuos, que acontecem muito rápido e sem paradas.

Interessante notar que a extrema compressão do tempo provoca um sentimento algo nostálgico. Ao resumir as experiências mais importantes de uma pessoa em apenas noventa segundos, o filme tende a relembrar o espectador da brevidade da vida. Pela beleza e ternura das situações apresentadas, porém, 
essa tendência não chega a se concretizar na forma de pesar ou melancolia.

Voltando à composição do programa emotivo, é necessário reconhecer o papel da música nesse sentido. A atmosfera sentimental e doce é sugerida desde as primeiras notas de piano, ainda nos planos iniciais, e se estabelece definitivamente com os versos cantados por Dangerfields. Com a passagem para a vida adulta, na cena do casamento, cordas são acrescidas à música - a ampliação da tessitura coincide com um momento narrativo importante. $O$ fato de a música ser tocada em sequência durante todo o filme (são três estrofes, excluído o refrão), sem interrupções ou mudanças, colabora no sentido de amarrar as diversas situações apresentadas.

Mas o aspecto mais relevante certamente é a letra da canção, que expõe, de forma lírica e subjetiva, características femininas a partir de uma perspectiva presumivelmente masculina. A letra também cumpre a função de sublinhar a ação, com frequência tratando daquilo que mostram as imagens - na cena em que a personagem reclama com a família enquanto tenta trabalhar, a canção diz "she's suddenly cruel"7.

Há ainda o fato de se tratar de uma música popular, composta em 1977 por Billy Joel. Certamente, é uma canção familiar aos ingleses, que remete a tempos passados, apesar da roupagem contemporânea fornecida pelo intérprete, líder de uma banda de indie rock. Em todo caso, a música possui uma carga semântica anterior ao filme que é recuperada na sua apreciação.

O texto, que frequentemente cumpre a função de fornecer sentido às imagens relacionando-as com o objeto publicitado, neste caso exerce um papel de complemento. Logo após o slogan da rede, a frase que surge na tela é "Our lifelong commitment to you" 8 . O intuito parece ser o de reforçar a ideia de um relacionamento de confiança e de longo prazo entre anunciante e consumidor/ espectador - de natureza semelhante às relações familiares exibidas anteriormente. O texto não explica nem fornece uma informação fundamental para a compreensão do filme, apenas reforça uma disposição já estabelecida pela apreciação da peça.

A título de síntese, é possível afirmar que Always a Woman é um filme cuja

7 Subitamente, ela é cruel (tradução nossa).

8 "O nosso compromisso para a vida inteira com você" (tradução nossa). 
PREMISSAS PARA APLICAÇÃO DE ANÁLISE FÍLMICA À PUBLICIDADE AUDIOVISUAL

estratégia de promoção e construção de imagem corporativa está fundamentada na produção de intenso engajamento emocional por parte do espectador. Estratégia poética que, por sua vez, baseia-se na identificação com personagens e situações apresentados; e engendrados através das sensações de fluidez e compressão temporais. O recurso musical também é utilizado na produção de sentimento. O esforço cognitivo, por sua vez, é minorado. O filme não solicita grandes manobras de raciocínio para ser compreendido, uma vez que a fábula, de natureza convencional, é apresentada de maneira temporalmente linear, e as elipses são camufladas por meio de ardis que forjam uma continuidade entre as diversas fases da vida da personagem. A narrativa, neste caso, concorre para a produção de um estado afetivo associado positivamente à percepção da marca John Lewis.

\section{CONCLUSÃO}

A análise de Always a Woman demonstra como pode ser frutífera a observação das relações entre as duas dimensões fundamentais do filme publicitário. Demonstra, sobretudo, a importância de se levar em conta os propósitos promocionais operando a partir de estratégias fílmicas. Uma análise de tais produtos sob esta perspectiva não deve prescindir da observação das relações entre a dimensão fílmica e o aspecto promocional do filme publicitário. Isso porque o resultado de uma análise que privilegiasse um dos aspectos em detrimento do outro seria ou uma visão meramente instrumental do objeto, cega às estratégias compostas por arte que dão suporte ao seu objetivo promocional; ou uma perspectiva ingênua, desprovida de instrumentos que permitam desvelar as motivações propriamente publicitárias por trás dos mecanismos fílmicos de produção de efeitos. Tal procedimento resultaria, em suma, em uma análise incompleta, manca, apenas parcialmente verdadeira.

Importa também ressaltar que estas premissas metodológicas se adequam à análise de diferentes formas de apresentação de materiais publicitários audiovisuais. Isso porque as duas dimensões estão sempre presentes, embora uma delas possa prevalecer. Basta pensar em ações que unem conteúdo, entretenimento e propaganda. É o caso do projeto The Hire, uma série de curtas de diretores consagrados encomendados pela BMW. Os filmes contam histórias diversas em que o produto do anunciante é apenas um elemento cênico. 
Não há argumento ou percepção de marca, apenas belas narrativas assinadas por grandes nomes do cinema mundial. Neste caso, a dimensão fílmica é mais relevante do que a promocional, uma vez que a própria estratégia de promoção da marca passa pela oferta de uma peça de entretenimento. Em um exemplo mais recente, Intel e Toshiba lançaram uma série de filmes para internet (The Beuaty Inside ${ }^{9}$ ), na qual o personagem principal tem uma característica peculiar: a cada dia, ele (ou ela) acorda como uma pessoa diferente. Trechos dos filmes são feitos com imagens de pessoas que enviaram vídeos de si mesmas via internet. O produto ou marca sequer aparece no filme, embora esteja no site e nas páginas em redes sociais que fazem parte da campanha. Neste caso, o engajamento do espectador é um efeito que deve ser produzido pelo filme para que ele se efetive enquanto estratégia de construção de uma marca.

Seja em se tratando dos convencionais filmes de trinta segundos, sejam formatos experimentais e híbridos, nos quais as fronteiras entre publicidade, entretenimento e conteúdo parecem se diluir, o que parece conveniente é a observação e a escrutinação dos elementos e modos de funcionamento de cada uma das dimensões do filme publicitário. Parece acertada, sobretudo, uma postura analítica que se enderece ao exame atento da relação entre os dois aspectos, das formas através das quais um programa poético se coloca a serviço do desígnio promocional em questão - ou vice-versa. É nesta relação que reside, certamente, a especificidade do filme publicitário frente a outros formatos audiovisuais - ao menos do que diz respeito ao seu aspecto imanente. E é esta indagação que permite enxergar os modos de acomodação entre os estratos essenciais do produto.

\section{REFERÊNCIAS}

ARISTÓTELES. Arte Poética. Tradução: Pietro Nassetti. São Paulo: Martin Claret, 2006. AUMONT, Jacques. A Estética do Filme. Tradução: Marina Appenzeller. São Paulo: Papirus, 1995.

AUMONT, Jacques; MARIE, Michel. Análisis del Film. Tradução: Carlos Losilla. Barcelona: Paidós, 1990.

9 A campanha, da agência Pereira e O’Dell de São Francisco, venceu Grand Prix na categoria Film no Festival de Cannes 2013. 
PREMISSAS PARA APLICAÇÃO DE ANÁLISE FÍLMICA À PUBLICIDADE AUDIOVISUAL

. Dicionário Teórico e Crítico de Cinema. 2. ed. Tradução: Eloísa Araújo Ribeiro. Campinas: Papirus, 2006.

BARRETO, Tiago. Vende-se em 30 Segundos: Manual do Roteiro para Filme Publicitário. São Paulo: Senac São Paulo, 2004.

BORDWELL, David. Narration in the Fiction Film. Madison: University of Wisconsin Press, 1985.

. Making Meaning: Inference and Rethoric in the Interpretation of Cinema. Cambridge: Harvard University Press, 1991.

Cannes Lions Festival. Archives. Disponível em: http://www.canneslions.com. Acessado em: $01 / 06 / 2008$

CASETTI, Francesco; CHIO, Federico Di. Cómo Analizar un Film. Tradução: Carlos Losilla. Barcelona: Paidós, 1991.

CHATMAN, Seymour. Coming to Terms: the Rhetoric of Narrative in Fiction and Film. Nova York: Cornell University Press, 1990.

ECO, Umberto. Lector in Fabula: a Cooperação Interpretativa nos Textos Narrativos. Tradução: Attílio Cancian. São Paulo: Perspectiva, 1986.

. Seis Passeios pelos Bosques da Ficção. Tradução: Hildegard Feist. São Paulo: Companhia das Letras, 1994.

GOMES, Wilson da Silva. Metáforas da Diferença. In: Revista Trans/Form/Ação v. 15. São Paulo: UNESP, 1992.

. Estratégias de Produção de Encanto: o Alcance Contemporâneo da Poética de Aristóteles. In: Textos de Cultura e Comunicação, n. 35, 1996.

. La Poética del Cine e la Cuestión del Método en el Análisis Fílmico. In: Significação, v. 21. São Paulo: Annablue, 2004.

. Princípios de Poética (com Ênfase na Poética do Cinema) in: PEREIRA, M.; GOMES, R.; FIGUEIREDO, V. (Org.). Comunicação, Representação e Práticas Sociais. $1^{\text {a }}$ ed. Rio de Janeiro: Editora PUC, 2004.

VANOYE, Francis, GOLIOT-LETÉ, Anne. Ensaio Sobre a Análise Fílmica. Tradução: Maria Appelenzeller. Campinas: Papirus, 1994.

RECEBIDO EM: 23/05/2013

ACEITO PARA PUBLICAÇÃO: 01/07/2013 


\section{Tatiana Guenaga Aneas}

Doutoranda do Programa de Pós-graduação em Comunicação e Cultura Contemporâneas da Universidade Federal da Bahia. Mestre pela mesma instituição. Especialista em Design de Comunicação Visual pela Universidade Salvador. Bacharel em Comunicação Social com habilitação em Jornalismo. Professora de cursos de Comunicação e Design da Universidade Salvador. 
